\section{文献}

（1）千葉 実，安藤 勉：日本金属学会誌，43(1979)， 1203.

（2）千葉 実, 安藤 勉: 分析化学, 31(1982), 179.

(3) R.F.Coleman: Analyst, 87 (1962), 590.

（4）藤井 勲，武藤治夫，三好克彦：分析化学，13 (1964), 249.

(5) W.F.Harris: Talanta, $11(1964), 1376$.

(6) J.M.A.Lenihan : Nucleonics, 23 (1965), No.2,65.

(7) I.Fujii, K.Miyoshi, H.Muto and K.Shimura: Anal. Chim. Acta, 34(1966), 146.
(8) B.L.Twitty and K.M.Fritz: Anal. Chem., 39 (1967), 527.

(9) R.van Grieken, A.Spsecke and J.Hoste : Anal. Chim. Acta, 51 (1970), 151.

(10) A.Adamek and F.Severa : Fyz. Cas., 21(1971), 215; Chem. Abstr., 76 (1972) , 80663a.

(11) 千葉 実：日本金属学会誌，43(1979)，947.

(12) W.J.Youden : Anal. Chem., 19 (1947), 946.

（13）実験化学講座・第 7 巻, 界面化学, 丸善, 東京, (1956), 942,

\title{
同位体希釈・スパークイオン源質量分析法による フェロアロイ，鉄鉱石，銑鉄中の硫黄定量*
}

\author{
斉 藤 守 $\mathrm{IE}^{* *}$ 須 藤 患美子***
}

\begin{abstract}
J. Japan Inst.Metals, Vol.46.No.7(1982),pp.691-695
Determination of Sulfur in Ferroalloys, Iron Ores and Pig Irons by Isotope Dilution-Spark Source Mass Spectrometry
\end{abstract}

\section{Morimasa Saito** and Emiko Sudo***}

\begin{abstract}
The determination of sulfur in ferroalloy, iron ore and pig iron by the isotope dilution method using ${ }^{34} \mathrm{~S}$ enriched sulfur, combined with spark source mass spectrometry, was studied. This method is based on a conventional gravimetric method. Samples are dissolved in nitric acid and hydrochloric acid containing potassium chlorate and the spike solution which is prepared by dissolving elemental ${ }^{34} \mathrm{~S}$ in nitric acid, and potassium chlorate is added to the solution. In ferrosilicon and high carbon ferrochrome samples, those are fused with sodium carbonate or sodium carbonate and sodium paroxide. The resulting solution is evaporated to drynass. The salts are dissolved in hydrochloric acid, and metallic zinc is added to reduce ferric ions to ferrous ions. Barium chloride is added to the solution to precipitate sulfur as barium sulfate, and then the precipitate is filtered and ignited. The ignited residue is mixed with graphite powder and pressed into electrodes.

The method was applied to the determination of sulfur in the JSS, NBS and BCS standard samples, and the results with satisfactory precision and accuracy were obtained for the analyzed samples except for ferrosilicon samples. The poor precision for ferrosilicon sample seems to be due to the blank of sulfur from reagents $\left(\mathrm{Na}_{2} \mathrm{O}_{2}\right.$, etc. $)$ used.
\end{abstract}

(Received January 25, 1982)

\section{I. 緒言}

鉄鋼製造における合金鋼の主要添加剂であるフェロマン ガン,フェロシリコン,フェロクロムなどのフェロアロイ， 原材料である鉄鉱石，あるいは銑鉄中の硫黄念有量を知る ことは重要である。
一般にフェロアロイ，鉄鉣石，銧鉄中の硫黄定量は，迅 速性にすぐれている然邺・中和滴定法など機器的分析法が 用いられているが，この方法は同種の標準試料を用いて溉 定される值を補正する必要がある。しかしながら。これら の金属の硫黄の標準試料に関しては燃燒法による硫黄の正 確な定量を行らに十分適用できる信頼性のある標集試料が

金属材料技術研究所 (National Research Institute for Metals, 'Tokyo)

*** 新日本製鉄株式会社基礎研究所 (Fundamental Research Laboratories, Nippon Steel Corporation, Kawasaki)

*1979 年 10 月日本分析化学会に 1 部発表；同位体希积・スパークイオン源䐝量分析法による金属中の不䋘物の 定量(第 2 報) 
整備されているとはい觉ないのが現状である。

フェロアロイに晾る硫黄定量の基準分析法としてはフ ェロマンガン，フェロシリコンは化学量論的分析洗による 重量法が用いられている(1)(2)。乙かし重量法は操作が煩雑 であり,フェロマンガン, フェロシリコンのよらに硫黄が 微量 $(0.01 \%$ 以下)に含有される試料に対しては定量が困 難であり，皇たつュロクロムは基準的分析法がないなど他 の基準となりらる分析法の確立が要望されている。

鉄鉱石，銑鉄に括ける基準分析法として，鉄鈉に準じ重 量法が JISに採用されているが(3)，この方法はフェロアロ 1 の場合と同様，微量硫黄を含有する試料に対しては問題 がある。市た鏡鉄には，基準的分析法として還元蒸留メチ

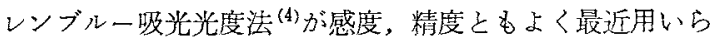
れるよらになったが，この方法による值と他の分析法との 比較検封が要望されている。

著者らは，先に鉄鎦中の硫黄定量に硫酸バリウム沈殿重 量法を利用した同位体希釈・スパークイオン源質量分析法 を適用し精度よく定量できることを報告した ${ }^{(5)}$ 。この方法 は一般的に用いられる方法ではないが，硫黄の絶対值を保 証できる定量法の1つと教えられたので，本法を用いてフ ェロシリコン，フェロマンガン，フェロクロムなどのフェ ロアロイ，種々の鉄鉣石，执よび銑鉄などの試料に応用し 良好な結果が得られたので報告する。

\section{II. 実験}

\section{1. 置, 試薬およびスパイク溶液}

実験には AE1 MS7 二重收束型買量分析器，イオン検出 には Ilford $\theta_{2}\left(2^{\prime \prime} \times 10^{\prime \prime}\right)$ 乾板を用いた、スペクトル線の黑 度测定には理学電機 (株) 製 CM-1A 型(観䁚スリット幅： $50 \mu \mathrm{m}$ ，測定主スりット幅 : $5 \mu \mathrm{m}$ ，スリット高さ $0.5 \mathrm{~mm}$ )

\section{ミクロホトメータ教用いて行なった。}

用いた試薬, 塩酸, 硝酸(SG1.42), 垛素酸カリウム, 塩化バリウム，两鉛 $(99.999 \%)$ ，炭酸ナトリウム，硝酸ナ トリウムは小宗化学 (株)製特級試薬である。過酸化ナトリ ウムはMerck 製，ふっ酸は東芝製特級試菜をそれぞれ用 いた。

スパイク用濃縮 ${ }^{34} \mathrm{~S}$ は Oak Ridge National Laboratory 製で，濃縮度約 $85 \%$ のものである、スパイク溶液の作成 は前報 ${ }^{(5)}$ と问じく，上㷉市販 ${ }^{34} \mathrm{~S}$ (単体) を碳酸之塩素酸力 リウムにて溶解した。スパイク溶液の硫黄濃度は $0.4 \mathrm{~kg} /$ $\mathrm{m}^{3}(\mathrm{mg} / \mathrm{mL})$ のるのを使用したが，フェロシリコン試料の 場合は, 試料溶解にアルカリ融解する関係上多量のスパイ ク溶液を添加するとけい酸が㠜固するのて傐浀度 $1 \mathrm{~kg} / \mathrm{m}^{3}$ $(\mathrm{mg} / \mathrm{mL})$ のスパイク溶液を使用した。スパイク溶液の添 加量は测定される ${ }^{34} \mathrm{~S}$ と ${ }^{32} \mathrm{~S}$ と同位体存在此が1になる 量に設定し希秎による愦差を最小にした。またフェロアロ イ、鉄鉱石，銑鉄試料之も共存元素の ${ }^{34} \mathrm{~S}{ }^{32} \mathrm{~S}$ のペク トル線への影響はない。

\section{2. 実験方法}

(1) フェロアロイ

フェロマンガンの場合の硫酸バリウム浣殿生成条件は JIS 重量法に準しだ1)。ただし，本法は重量法のように䋓 対量を求める方法でないので洗浄その他簡略化した。試料 約 $5 \mathrm{~g}$ にスパイク溶液を添加後，塩素酸カリウム $1 \mathrm{~g}$ 子 硝酸 $50 \mathrm{~cm}^{3}$ を加壳て溶解する。必要があれば加熱する。加 熱乾国後, 温度 $383 \mathrm{~K}\left(110^{\circ} \mathrm{C}\right)$ で約 $1.8 \mathrm{ks}(30 \mathrm{~min})$ 間加熱 する、冷却後，塩酸 $30 \mathrm{~cm}^{3}$ を加告培を加熱溶解しシロッ プ状になるまで加熱蒸発する。塩酸 $10 \mathrm{~cm}^{3}$ と水 $25 \mathrm{~cm}^{3}$ を 加えて加熱した後，ろ紙 5 種 B と少量のろ紙パルプを用い てろ過し，塩酸 $(2+100)$ で 2 回洗浄する。液と洗液とを 一緒にし，加熱し $30 \mathrm{~cm}^{3}$ にして两鉛約 $5 \mathrm{~g}$ を加衣，333〜 $343 \mathrm{~K}\left(60 \sim 70^{\circ} \mathrm{C}\right)$ の温度に保って第 2 鉄を第 1 鉄に還元す る、万紙 5 種 Cを用いてろ過し, 塩酸 $(1+99) 70 \mathrm{~cm}^{3}$ で洗 浄した後，333 $343 \mathrm{~K}$ の水浴上で加熱し，かきまぜなが ら塩化バリウム溶液 $(10 \%)$ を $10 \mathrm{~cm}^{3}$ 加えここの温度で $7.2 \mathrm{ks}(2 \mathrm{~h})$ 保ら，さらに室温にて 1 夜間放置する。万紙 5 種Cを用いてろ過し，熱水で 1 回洗浄寸る，洗浄後，万紙 と共に白金るつ后に移し, 徐々に加熱, $1073 \mathrm{~K}\left(800^{\circ} \mathrm{C}\right)$ の温 度にして強熱灰化する，灰化物存メノ一乳鉢飞移し，細名 く粉研した後高純度黑雓粉末 (National Carbon Co. 分光 分析用, ペレット用(SP-11) 約 $200 \mathrm{mg}$ を加光，プラスチ ック製容器にタングステン製ボールと共に入れ, Spexの ミキサーミル(No.8000)にて約 $900 \mathrm{~s}(15 \mathrm{~min})$ 間 (2 回に分 ける)混合する，混合物を $\phi$ 約 $2.5 \mathrm{~mm}$ の穴のあいたポり エチレンスラグに入れ，AE1 製サンプルモールドによっ て電極を 2 本作成する。

質量分析の測定条件は主スリット $120 \mu \mathrm{m}$ ，又パーク電 压約 $40 \mathrm{kV}$ ，パルス繰り返乙数 $10 \sim 300 \mathrm{~Hz}$ ，パルス幅 $25 \mu \mathrm{s}$ ，イオン加速電压 $20 \mathrm{kV}$ である。露出量は $3 \times 10^{-10}$ C, $1 \times 10^{-9} \mathrm{C}$ の 2 種類を繰り返し測定子る。乾板の現像は ID $-13,293 \mathrm{~K}\left(20^{\circ} \mathrm{C}\right)$ て $180 \mathrm{~s}(3 \mathrm{~min})$ 行い, 定着はフジフィ ックス定着液索使用し $300 \mathrm{~s}(5 \mathrm{~min})$ 間行う，水洗は $1.8 \mathrm{ks}$ (30 min)間行なった後，自然乾燥する。

${ }^{32} \mathrm{~S}{ }^{34} \mathrm{~S}$ の同位体のスペクトル線の相対強度計算には ${ }^{194} \mathrm{Pt}$ と ${ }^{196} \mathrm{Pt}$ の同位. 体を用いる Churchill 2 線法 ${ }^{(6)}$ にっ て求めた，定量計算式拉よび計算に必要な天然硫黄，スパイ ク用濃綰 ${ }^{34} \mathrm{~S}$ の同位体存在度の值は前報の值を用いた ${ }^{(5)}$ 。

フェロクロム試料の場合, 低炭素つェロクロムと高炭素 フェロクロムとでは試料溶解法が異なるので低若素フェ口 クロムと高崖素フェロクロムとに分けて実駼操作を下記に 述へる。

低宸素フェロクロム約 $5 \mathrm{~g}$ を塩素酸カリウム $1 \mathrm{~g}$ と硝酸 と塩酸 $(1+4)$ の湦酸 $60 \mathrm{~cm}^{3}$ を加之た後，スパイク溶液を 添加，加熱溶解する。この混酸で溶解しない場合は硝酸と 程酸 $(1+6)$ の混酸で溶解する，溶解後さらに加熱を続け蒸 発乾固し， $423 \mathrm{~K}\left(150^{\circ} \mathrm{C}\right)$ の温度にして $1.8 \mathrm{~s}$ 間加熱する。 
冷却後, 塩酸 $(1+1) 30 \mathrm{~cm}^{3}$ を加兄可溶性塩類を溶解し,

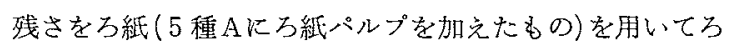
過し，塩酸 $(2+100)$ で 2 回洗浄する。，その後の操作はフェ ロマンガン化準じて操作する。

高炭素つェロクロムは上述の混酸では溶解しないのでア ルカり融解する。すなかち，試料 $3 \mathrm{~g}$ を白金るつぼ中で硝 酸ナトリウムと無水炭酸ナトリウムの融解合剂 $(1+10) 20 \mathrm{~g}$ で融解する。冷却後, 塩酸 $(1+1)$ 拉よび水で融解物を溶解 し，スパイク溶液を添加する。加熱蒸発し液量を $10 \mathrm{~cm}^{3}$ と

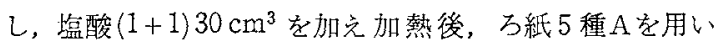
てろ過する，塩酸 $(2+100) て ゙ 2$ 回洗浄した以後の操作，質 量分析の測定条件，計算方法はフェロマンガンに準じて行 なう。

フェロシリコンの場合の実験操作性 JIS 重量法 ${ }^{(2)}$ に準じ て行なった。すなわち、試料 $2 \mathrm{~g}$ をニッケルるつぼ $\left(50 \mathrm{~cm}^{3}\right)$ に入れ，炭酸ナトリウム $12 \mathrm{~g}$ を加えてふなをし予備融解 する，放冷後，過酸化ナトりウム $8 \mathrm{~g}$ 省加克て再び融解す る. 冷却後, 温水約 $200 \mathrm{~cm}^{3}$ を加兄て溶解し，るつばは温 水て洗って取り出す．約 $300 \mathrm{~s}$ 間募沸してろ紙 $(5$ 種 B )を 用いてろ過し，温水酸化ナトリゥム溶液 $(1 \%)$ で 3 回洗 浄する。スパイク溶液を添加後，かき亲な゙な゙ら塩酸 $60 \mathrm{~cm}^{3}$ 徐々に加兄, 水浴上で蒸発乾固し, 放冷後残さ を塩酸で湿し，再び水浴上で蒸発乾固した後，約 $393 \mathrm{~K}$ の 温度で約 $3.6 \mathrm{ks}(1 \mathrm{~h})$ 加熱する. 以後の操作は洗清などを 簡略する以外は IIS 重量法と同じであるので JIS 拉上びフ ェロマンガンの笑験操作を参照する。

\section{(2) 鉄鈯石}

鉄鉱石試料は JIS 重量法 ${ }^{(3)}$ 亿準じた。試料の前処理は鉄 鉱石分析方法通則によった ${ }^{(7)}$. 恒温乾燥後, 試料 $5 \mathrm{~g}$ を塩 素酸カリウム $1 \mathrm{~g}$ を加兄，水少量を添加，十分飞振りまぜ スパイク溶液を加光た後，硝酸之塩酸 $(1+4)$ の混酸を加 光, 徐々加熱して溶解する。溶解後，約 $423 \mathrm{~K}$ のサンド バス上で蒸発乾固する。冷却後, 塩酸 $10 \mathrm{~cm}^{3}$ を加穴再び $150^{\circ} \mathrm{C}$ の温度で蒸発乾固し，引き続き $1.8 \mathrm{ks}$ 間加熱する。 塩酸 $10 \mathrm{~cm}^{3}$ を加方て静か儿加熱し可溶性壏を溶解し，水 約 $25 \mathrm{~cm}^{3}$ を加克 $1.2 \mathrm{ks}$ 間㟟沸する。万紙 5 種Cを用いて 不溶解残さを万過し，塩酸 $(2+100)$ で 2 回洗浄する。不溶 解残さ中に硫黄が含む場合はアルカリ融解する(JIS 法参 照 $\left.{ }^{(3)}\right)$ 。それ以後の操作はフェロマンガンのとをと同じで 哭る。

\section{(3) 銑鉄}

銑鉄試料の場合は，鉄拉よび鐥の硫黄定量の重量法 ${ }^{(4)}$ に 準して行なら。すなわち, 試料 $5 \mathrm{~g}$ に硝酸と塩酸 $(1+1) の$ 混酸 $50 \mathrm{~cm}^{3}$ 之睢素酸カリウム $1 \mathrm{~g}$ 加光，スパイク溶液 を添加後，徐々に加熱して溶解する、溶解しない残渣は炭 酸ナトリウムと硝酸ナトリウム $(10+1)$ の融解合剤にて融 解する以外はフニロマンガン，鉄鋼の場合 ${ }^{(5)}$ 之同じである のでそれを参照する，以後質量分析用試料作成などはフェ ロマンガンに集じる。

\section{III. 結果および考察}

\section{1，試薬類の硫黄空試験}

試料の溶解に使用した塩酸，硝酸などの試薬中に硫黄が わずかであるが含有し，0.003\% 以下の硫黄を含有する試

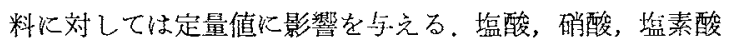
カリウム，带鉛，それ飞電極支持体である黑鉛粉束につい ては検討ずみであるので(5)，フェロフロイ，鉄鉣石，銑鉄 陚料の溶解に用いる上述以外の試薬について検討した。検 討した試薬は, 硝酸ナトリウム, 無水炭酸ナトリウム，過 酸化ナトりウムで，溶解のさいの使用量に対して同位体希 釈法を用いてブランク値を求めた。 その結果を Table 1 に示す、硝酸ナトリウム，無水炭酸ナトりウムには硫黄含 有量は少ないが，過酸化ナトリウム(Merck 製) は硫黄がわ ずかであるが存在した，過酸化ナトりウムはフェロシリコ ン試料の溶解に用いられるが，フェロシリコンは硫黄含有 量が微量であるのでその試薬の影響があると考兄られる。 実際の定量計算《はこれら試薬からの硫黄ブランク值を差 引いて定量值を求めた。

Table 1 Determination of blank values of sulfur in reagents used.

\begin{tabular}{l|c|c}
\hline \multicolumn{1}{c|}{ Materials } & $\bar{x}(\mu \mathrm{g}),(n=6)$ & $\sigma(\mu \mathrm{g}) * * *$ \\
\hline $\mathrm{NaNO}_{3} *(2 \mathrm{~g})+\mathrm{Na}_{2} \mathrm{CO}_{3} *(20 \mathrm{~g})$ & 2.3 & 0.31 \\
$\mathrm{Na}_{2} \mathrm{O}_{2} *(8 \mathrm{~g})+\mathrm{Na}_{2} \mathrm{CO}_{3} *(12 \mathrm{~g})$ & 7.1 & 1.9 \\
$\mathrm{Na}_{2} \mathrm{CO}_{3} *(3 \mathrm{~g})+\mathrm{Hf} * *\left(5 \mathrm{~cm}^{3}\right)$ & 0.21 & 0.07 \\
\hline
\end{tabular}

\footnotetext{
* Special grade (Koso Chemical Co)

** Special grade (Toshiba Elec. Co)

*** Standard deviation
}

\section{2. 定量結果}

\section{(1) フェロアロイ}

フェロマンガン中の硫黄定量の検討は，日本鉄銅協会標 準試料 JSS 701-1 と NBS 68B の 2 種類を用い, その結果を Table 2 に示す. Table 2 から分かるように，本法に上る 值は標集值とかなりよい一致を示しているが，JSS 701-1 の試料では本法による值は標準值より少し高い仵が得ら れ，これに対してNBS 68B の試料では標準值より少し低 い值が得られた。これは標淮値の決定方法が異なったため の差と考光られる。しかし、フェロマンガンの標準試料は

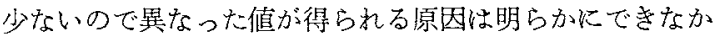
ったがさらに多くの試料について比較検詰が必要である 5. 本法による精度は独立 6 回測定して变動係数で $3.9 \%$ 以内であった。

フェロクロムの検討には，低炭菜フェロクロムJSS 730-1 (C: $0.074 \%) と$ BCS 203-2(C: 0.027\%)を，高炭素〉= ロクロム ISS 731-1(C: 7.80\%) と BCS 204-1 (C : 4.56\%) の 4 種類の標準試料を用いた。その定量結果を Table 2 に 示寸。

低炭素フェロクロムに関しては，JSS 730-1の本洗によ 
Table 2 Analytical results of sulfur in ferromanganese, ferrochrome and ferrosilicon.

\begin{tabular}{c|c|c|c|c}
\hline Sample & $\begin{array}{c}\text { Certified value } \\
(\%)\end{array}$ & $\bar{x}(\%)^{*}$ & c.v. $(\%)^{* *}$ & Note \\
\hline Ferromanganese & & & & \\
JSS701-1 & 0.007 & 0.00753 & 2.73 & $\mathrm{Mn}: 76.62 \%$ \\
NBS68B & 0.006 & 0.00538 & 3.90 & $\mathrm{Mn}: 79.97 \%$ \\
Ferrochrome & 0.007 & 0.00652 & 3.82 & $\mathrm{C}: 0.074 \%, \mathrm{Cr}: 62.7 \%$ \\
JSS730-1 & $0.002 \sim 0.006)$ & 0.00411 & 6.13 & $\mathrm{C}: 0.027 \%, \mathrm{Cr}: 71.7 \%$ \\
BCS203-2 & 0.026 & 0.0295 & 4.00 & $\mathrm{C}: 7.80 \%, \mathrm{Cr}: 61.5 \%$ \\
JSS731-1 & 0.03 & 0.0340 & 5.25 & $\mathrm{C}: 4.56 \%, \mathrm{Cr}: 66.3 \%$ \\
BCS204-1 & & 0.00345 & 8.02 & $\mathrm{Si}: 76.90 \%$ \\
Ferrosilicon & & 0.00391 & 9.20 & $\mathrm{Si}: 75.94 \%$ \\
JSS720-2 & & & \\
ISS720-3 & & &
\end{tabular}

* Average of 6 determinations ** Coefficient of variation

る定量結果は 6 回独立に湘定して $0.00652 \% ，$ 精度は 3.82 $\%$ で標準值0.007\%とよい一致を示した。 また，BCS 2032 の試料に対しては硫苠定量值は $0.00411 \%$ ，精度は

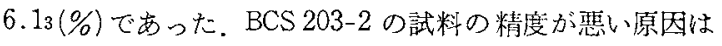
試料の偏析によると思われる。

高炭素フェロクロムに関しては, JSS 731-1の試料では 標準値 $0.026 \%$ K対し本法による值は 6 回独立に測定して $0.0295(\%) ， 4.00(\%)$ 精度であり，本法による值が幾分高 い値を示したが，BCS 204-1 の試料では標準值 0.03\% に 対して本法による值は $0.0340(\%)$ ，精度 $5.25(\%)$ であり， 両者はかなりよい一致を示したが本法が少し高い值を示 す。このように試料によって異なった傎向を示した原因 は，各国の標準值決定方法の差と日考えられ，ぬたフェ口 クロム中の硫黄定量に用いられる燃漭・中和滴定法 ${ }^{(8)}$ は完 今に試料が燃焼され $100 \%$ 硫黄が回収されることを前提に した方法であり基集的分析法とはいえないためとる考えら れ，さらに詳しいことは多くの試料を比較倹諳する必要吕 あらら。

フェロシリコン中の硫黄定量は燃焼法, 重量法が JIS に 規定されているが(2)，奏祭には然焼しにくい試料があり， 燃㟝法で定量するのは困難である。重量法る硫黄含有量が 徵量 $(0.005 \%$ 以下)であるので定量がむずかしい，本法は 感度が高い力法でするのでフェロシリコンのような試料で も定量できる、検討した試料は日本鉄鋼協会標準試料 JSS 720-2,720-3である.その結果を Table 2 亿示す. ISS 720-2 己 JSS 720-3 の各試料厄対して $0.00345(\%)$ ，精度 は 8.02 (\%)と $0.00391 \%$ ，精度は 9.20(\%)であった。フ ェロシリコンの場合精度が比輍的悪いが，これは陚料偏析 の及ならず，使用した試薬過酸化ナトリウムによる硫黄の ブランクの影響が大きいためと芹えられる。ささらに精度よ く走量するには試薬からのブランクを下げる必要がある。

\section{（2）鉄 鉱 石}

鉄鈗石の標準試料について検討し得られた定量結果を Table 3 K示す。用いた試料は日本鉄銅協会標準試料 JSS 801-3(Indian hematite), JSS 800-3(Rompin hematite),
Table 3 Analytical results of sulfur in iron ores.

\begin{tabular}{l|c|c|c}
\hline \hline \multicolumn{1}{c|}{ Sample } & $\begin{array}{c}\text { Certified } \\
\text { value(\%) }\end{array}$ & $\vec{x}(\%)^{*}$ & $\mathrm{c.v} .(\%) * *$ \\
\hline $\begin{array}{l}\text { JSS801-3 } \\
\text { (Indian hematite) }\end{array}$ & 0.006 & 0.00624 & 5.20 \\
$\begin{array}{l}\text { JSS 800-3 } \\
\text { (Rompin hematite) }\end{array}$ & 0.074 & 0.0738 & 4.12 \\
$\begin{array}{l}\text { JSS820-1 } \\
\text { (Roberiver) }\end{array}$ & 0.027 & 0.0297 & 9.06 \\
$\begin{array}{l}\text { JSS850-3 } \\
\text { (Marcona pellet) }\end{array}$ & 0.018 & 0.0186 & 5.30 \\
$\begin{array}{l}\text { JSS851-2 } \\
\text { (Sintered) }\end{array}$ & 0.014 & 0.0135 & 4.25 \\
$\begin{array}{l}\text { BCS175-1 } \\
\text { (Liberian) }\end{array}$ & 0.034 & 0.0347 & 4.94 \\
\hline
\end{tabular}

* Average of 6 determinations

** Coefficient of variation

JSS 820-1 (Roberiver), JSS 850-3(Marcona pellet), JSS 851-2(Sintered)，それにBCS 175-1(Liberian)である。

Table 3 に示すよ 5 K JSS 820-1 の陚料を除いて本法によ る値は標準値と非常によい一致を示した、精度も6 回独立 に湘定して変動係数にして $6 \%$ 以内であった。

JSS 820-1 の試料に関しては本法による值が標準做より 高い值を示し，また精度も悪い結果が得られた。この原因 は明らかでない。

\section{(3) 銑 鉄}

銑鉄中の硫黄定量は，鉄鍼試料に潗じて行らことになっ ている。しかし燃焼法では完全に硫黄が回収されない場合 があり (9)，また重量法では白銑試料の場合炭素の影響があ るといわれ，影響をとり除く操作を必要とする(10). 最近 はメチレンブルー吸光光度法が準基準分析法として用いら れるよらになったが，この方法による值と比較検討をか的 て本法を用いて銑鉄のみならず鋳鉄についても検討した。 その結果を Table 4 に示す。試料は日本鉄鋼協会標準試 料 JSS 110-4, JSS 112-3, JSS 110-6, JSS 102-3, S-31, NBS 341 (Ductile), NBS $7 \mathrm{~g}$, NBS $82 \mathrm{a}$ (Ni-Cr cast), NBS 3 (White)である。本法による値は標準值とよい一致あるい は幾分高值を示す傾向があった，鉄銅試料では本法による 
Table 4 Analytical results in pig iron and cast iron.

\begin{tabular}{l|l|l|c|c}
\hline \hline Sample & $\begin{array}{l}\text { Certified } \\
\text { value }(\%)\end{array}$ & $\bar{x}(\%) *$ & c.v. $(\%) * *$ & Note \\
\hline JSS102-3 & $0.0246 * * *$ & 0.0251 & 3.13 & \\
JSS110-4 & 0.041 & 0.0439 & 5.96 & \\
JSS110-6 & 0.033 & 0.0345 & 3.52 & \\
JSS112-3 & 0.022 & 0.0209 & 5.50 & \\
S-31 & $0.0109 * * *$ & 0.0119 & 3.93 & \\
NBS7g & 0.060 & 0.0632 & 4.06 & \\
NBS82a & 0.102 & 0.108 & 4.03 & Ni-Cr cast \\
NBS3 & 0.090 & 0.0876 & 3.47 & White \\
NBS341 & 0.007 & 0.0072 & 4.21 & Ductile \\
\hline
\end{tabular}

* Average of 6 determinations

** Coefficient of variation

*** Values obtained by the absorptiometric method by Methylene Blue

値は標淮值より低値を示す傾向があったが，銑鉄などの試 料は久の逆の㑯向があった，鉄鋼試料では然焼法の基準值 の取り方に問題があったが，銛鉄陚料の場合は然焼法によ ると一般に然焼時に試料が飛び散るおとれがあり，助然剂 が問題になっているが，そのための低值とる考えられる。 精度は JSS 110-4, JSS 112-3 試料以外は 5\% 以内であっ た. 上記 2 種類の試料の精度が覀いのは試料の腐析のため と考えられる。

$$
\begin{gathered}
\text { IV. 結 論 } \\
\text { フェロマンガン, フェロクロム, フェロシリコンのフェ }
\end{gathered}
$$
ロアロイ，鉄鉣石，銑鉄中の硫黄定量を硫酸バリウム沈殿 重量法を利用した同位体希釈・スパークイオン源質量分析 法により検討し，次の結論を得た。

フェロアロイに関しては正確さ，精度ともかなりよい值 が得られ，標準值と比較検討し良好な結果が得られた。し
かしフェロシリコンに関してははじめて硫黄量を明らかに することができたが，使用した試蒋(融解合剂)の硫黄フラ ンクの影響があり精度は6 回測定に8〜9％）と悪かった。 さらに精度をよくするには試薬からのブランクの影響を小 さくする必要がある。本法はその他のフェロアロイ，たと えばフェロニオブ，フェロバケジウム，フェロタングステ ソ中の硫黄定量に応用できる。

鉄鉱石試料火関しては本法による值はJSS 820-1(Roberiver)を除いて標準値とよい一致を示した。

銑鉄試料に関しては本法による值は標準值と一致あるい は幾分高い值を示古試料が多かった，これは然焼法の燃焼 時に問題のためと考兄られ，さらに多くの試料について 検討する必要がある。

本法は一般的万法とはいい難いが，原理的には正確さの

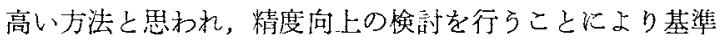
分析法のすぐれた一つをなりらると思われる。

\section{文献}

(1) JIS G1311(1974).

(2) JIS G1312(1977).

(3) JIS M8217 (1971).

(4) JIS G1215(1980).

(5) 者藤守正, 須藤患美子：分析化学，30(1981)，281.

(6) J.R.Churchill : Ind. Eng. Chem. Anal. Ed., 16 (1949) , 653.

(7) JIS M8216(1971).

(8) JIS G1313(1978).

（9）広間勉，大由修明，藤村正信，後藤能紀，原田 芳文，三浦弘行：福滋県金属工業試験場研究報告， 1977 (1979)， 110.

(10) 成田貴一，谷口政行，太田法明，小谷直美，正藤 武：鉄乙墭，64(1978)，631。 